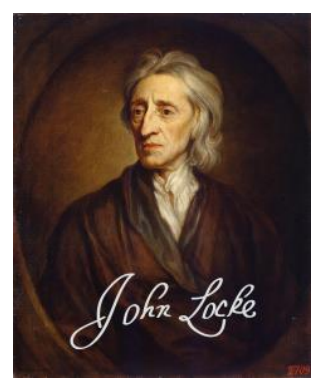

LOCKE STUDIES

Vol. 17

https://doi.org/10.5206/ls.2017.888 | ISSN: 2561-925X

Originally published: 2017

Published online: 01 JANUARY 2019

(C) Locke Studies, 2017

\title{
Locke and the Churchill Catalogue Revisited
}

\author{
JOHN SAMUEL HARPHAM (HARVARD UNIVERSITY)
}

Recommended citation:

Harpham, John Samuel. "Locke and the Churchill Catalogue Revisited." Locke Studies 17 (2017): 23341. https://doi.org/10.5206/ls.2017.888.

For more information about this article:

see this article's webpage.

Locke Studies is published by The John Locke Society.

This is an open access article published under the terms of the Creative Commons Attribution-

NonCommercial-ShareAlike 4.0 International license, which permits use, distribution and reproduction in any medium, provided the original work is properly cited and shared under the original license. 


\title{
LOCKE AND THE CHURCHILL CATALOGUE REVISITED
}

\author{
JOHN SAMUEL HARPHAM
}

At the time of his death, in 1704, the library of John Locke held 269 volumes of philosophy - but 275 volumes of geography and travel. Works of geography drew on discoveries related in books of travel, but Locke did nevertheless see them as distinct genres. In both, his holdings were extensive. He owned several volumes of maps; the great recent surveys of Africa, America, and Japan printed by John Ogilby; and the descriptions of the world by Abbot, Purchas, Morden, and Moll. It was in books of travel, though, of which Locke owned 195, where his holdings were most remarkable. He owned the massive collections of Ramusio (in Italian), de Bry (in Latin), Thévenot (in French), and Hakluyt and Purchas (in English). He owned accounts of the well-known voyages of Hariot to Virginia, de Léry to Brazil, Sandys to the Ottoman Empire, Gage to the West Indies, and Choisy to Siam. He owned as well accounts of dozens of more minor voyages, such as those of Blount to the Levant, Monconys to Syria, Ray to the Continent, Josselyn to New England, and Fryke to the East Indies. No student of Locke's library has failed to remark upon what Harrison and Laslett, its modern editors, have called its 'great strength' in these areas. ${ }^{1}$ This is to understate the matter,

${ }^{1}$ John Harrison and Peter Laslett, eds., The Library of John Locke (hereafter: LJL) (Oxford, 1971; orig. pub. 1965), 27. The works mentioned here by name appear in order, according to their numbers in the Library, as LJL 2124; LJL 2125; LJL 2126; LJL 2a; LJL 2409 (vol. 5); LJL 2042; LJL 2009; LJL 2438; LJL 510; LJL 2889-2890; LJL 1374; LJL 2409; LJL 1384-1385; LJL 1717-1718; LJL 2553; LJL 1205; LJL 693; LJL 359; LJL 2016; LJL 2446; LJL 1588; and LJL 1198. Locke also was aware of, but did not own, the other major seventeenth-century English description of the world: Peter Heylyn, Cosmographie (London, 1652). (See John Locke, 'M ${ }^{\mathrm{r}}$ Locke's Extemporè Advice \&c.' in John Locke, Some Thoughts Concerning Education, eds. John W. and Jean S. Yolton [Oxford, 1989], 319-27, 323.) Data on numbers of volumes, sorted by genre, appear in Harrison and Laslett, $L J L, 18$. For the distinction Locke drew between geography and books of travel, which Harrison and Laslett have preserved, see Locke, 'Ex- 


\section{for it seems that among libraries of its size in late Stuart England, only the library of Robert Hooke (and perhaps that of Robert Boyle) rivalled Locke's in works of geography and travel. ${ }^{2}$}

temporè Advice', 323. On Locke's library, see Helen Campbell Hughes, 'John Locke's Library', The Book Collector's Quarterly, 12 (1933): 32-40; Richard Ashcraft, 'John Locke's Library: Portrait of an Intellectual', in John Locke: Critical Assessments, ed. Richard Ashcraft, vol. 1 (New York, 1991), 17-31; Ann Talbot, 'Locke's Travel Books', Locke Studies 7 (2007): 113-35; and Felix Waldmann, 'The Library of John Locke: Additions, Corrigenda, and a Conspectus of Pressmarks', Bodleian Library Record 26 (2013): 36-58. It should also be noted, as James Farr has established, that Locke himself contributed to the genre of geography as '(principal) author' of the section on Carolina in Ogilby's 1671 America: see James Farr, 'Locke, 'Some Americans', and the Discourse on 'Carolina', Locke Studies 9 (2009): 17-96, at 21.

${ }^{2}$ Hooke's final library, listed in the form of the auction catalogue for its contents that was arranged after his death in March 1703, has been printed in Leona Rostenberg, The Library of Robert Hooke: The Scientific Book Trade of Restoration England (Santa Monica, CA, 1989). It is difficult to give a general sense of its holdings, since the catalogue is organized by the size of works and their language rather than subject or in alphabetical order; but Rostenberg gives a survey of Hooke's books of geography and travel on 135-40, and no glance at any section of the catalogue can fail to impress the reader with its contents in these fields. On the other hand, no catalogue of Boyle's library has survived; but references to travel books in his writings indicate that his collection was indeed very great (see Iordan Avramov, Michael Hunter, and Hideyuki Yoshimoto, Boyle's Books: The Evidence of his Citations [London, 2010]). Locke and Boyle were friends until Boyle's death in 1691; and as Daniel Carey has observed, Locke studied Boyle's works for references to useful travel books, which the two also discussed in personal correspondence. See Daniel Carey, 'Travel, Geography, and the Problem of Belief: Locke as a Reader of Travel Literature', in History and Nation, ed. Julia Rudolph (Lewisburg, PA, 2006), 97-136, at 103-104. Finally, it should be noted that in their edition of Locke's library, Harrison and Laslett observed what they called a 'really remarkable resemblance, or, in this case, near identity' of Locke's travel books with those of Isaac Newton; and this observation was quoted with approval in Carey's otherwise thorough and incisive article. Harrison and Laslett, LJL, 13 (see Carey, 'Travel, Geography, and the Problem of Belief', 124 [fn. 33]). But this observation is inaccurate, for in fact in his edition of Newton's library Harrison himself reported that recent research had led him to conclude that he and Laslett had 'exaggerated the similarity of the two libraries in the field of travel literature'. John Harrison, 'The Composition of Newton's Library', in The Library of Isaac Newton, ed. John Harrison (Cambridge, 1978), 58-78, 67 (fn. 4). And as only a glance at the catalogue of his library is required to impress the reader with the extent of Hooke's holdings, so only a brief acquaintance with the contents of Newton's library will convince the reader of its paucity. Newton held only thirty-six volumes of geography and forty volumes of voyages and travel, and at least several of these were works printed after 1704. Of the collections and books of travel mentioned in the text above as in the possession of Locke, Newton did not own a single one. 
Little under a year before Locke's death, Awnsham and John Churchill — who had published Locke's Two Treatises of Government, in 1690 - released a four-volume Collection of Voyages and Travels, which was the most important English work of its kind since the 1625 Pilgrimes of Samuel Purchas. The text compiled from manuscript sources or translated out of several languages thirty-four accounts of journeys to Japan, Iceland, Ukraine, Chili, and the Cape of Good Hope, among others; and it included, in addition, an 'Introductory Discourse' divided into an extended 'History of Navigation' and a 'Catalogue and Character of most Books of Travels'. In 1704, as well as in 1732 (when an expanded six-volume edition was brought out), neither of these prefatory writings was attributed to a named author. But in 1744, the title page to a third edition of the Collection noted that the Discourse (by which it meant only the History) was 'supposed to be written by the Celebrated Mr. LOCKE'. No material from the Churchill Collection was published in the first eight editions of Locke's collected Works. The editor's preface to Edmund Law's eighth edition (1777), though, identified both pieces of the Discourse as works 'written, or supposed to be written, by Mr. Locke'; and indeed, in the ninth edition, in 1794, both the History and the Catalogue were included. Through 1823, both texts were re-printed in three more editions of Locke's Works. Since then, neither one has appeared in any edition of Locke. 'Modern criticism', moreover, remarked E. S. de Beer (the editor of Locke's Correspondence) in 1976, 'is averse to the attribution'. ${ }^{3}$

${ }^{3}$ A Collection of Voyages and Travels, (4 vols., London, 1704), ix-lxxvi ('History') and lxxvi-c ('Catalogue'); A Collection of Voyages and Travels (6 vols., London, 17441746), title page; [Edmund Law], 'Preface by the Editor', in The Works of John Locke (4 vols., London, 1777), I, iii-xx, iv; and E. S. de Beer, 'Bishop Law's List of Books Attributed to Locke', The Locke Newsletter 7 (1976): 47-54, 50. See also: A Collection of Voyages and Travels (6 vols., London, 1732); The Works of John Locke (9 vols., London, 1794), IX, 358-512 ('History') and 513-54 ('Catalogue'); and The Works of John Locke (10 vols., London, 1823), X, 357-512 ('History') and 513-54 ('Catalogue'). For the judgment of de Beer, see also G. R. Crone and R. A. Skelton, 'English Collections of Voyages and Travels, 1625-1846', in Richard Hakluyt and His Successors, ed. Edward Lynam (London, 1946), 63-140, at 81-84; Maurice Cranston, John Locke: A Biography (London, 1957), 463; and The Correspondence of John Locke (hereafter CJL), ed. E. S. de Beer (8 vols., Oxford, 1976-), VII, 172-73 (fn. 1). 
The aversion described by de Beer has continued to the present day. ${ }^{4}$ To be sure, Locke seems unlikely to have composed the History, whose bland style and almost obsessive attention to the technical details of navigation find no parallel in Locke's published and manuscript writings. (The work has in fact plausibly been attributed to the astronomer Edmond Halley [1656-1742]. $)^{5}$ Following Edmund Law, scholars have tended to assume that the same author must have been responsible for both the History and the Catalogue. But of course this need not have been so; and indeed, the Catalogue, a project of a character very different from that of the History, may well have been in part the work of 'the Celebrated Mr. LOCKE'.

Locke was intimately involved in the Churchill Collection from the beginning. Throughout the years of its production, from 1700 to 1703 , Awnsham often sought Locke's advice on works to include, and sent him several recent books of travels to peruse; and in turn, Locke searched for copies of rare accounts he thought should appear in the Collection. Months before the Churchills' masterpiece was published, in late 1703, Awnsham sent to Locke an unbound copy of its first volume; and once the work appeared in print, he thanked him warmly for his assistance. When Locke died, in late 1704, his library included the first edition of the Collection, which Awnsham had promised to send. In the codicil to his will, he left to the Bodleian the anticipated fifth and sixth volumes of what would become the second edition of the Collection,

\footnotetext{
${ }^{4}$ See Daniel Carey, 'Locke, Travel Literature, and the Natural History of Man', The Seventeenth Century 11 (1996): 259-80, at 261; Jean S. Yolton, John Locke: A Descriptive Bibliography (Bristol, 1998), 432-33; Talbot, 'Locke's Travel Books', 130; and idem, "The Great Ocean of Knowledge": The Influence of Travel Literature on the Work of John Locke (Leiden, 2010), 222-23. Adopting Law's categories for attribution, but shifting the place of the History and Catalogue within these categories, Yolton included both works among Locke's 'Doubtful and Spurious Works'. Yolton, Descriptive Bibliography, 432. The sole modern attribution of the Catalogue to Locke, made principally on the basis of his correspondence with Jean-Baptiste du Bos (discussed below), appeared in Gabriel Bonno, 'Une amitié franco-anglaise du XVIIe siècle: John Locke et l'Abbé du Bos', Revue de Littérature Comparée 24 (1950), 481-520. See also Gabriel Bonno, Les Relations intellectuelles de Locke avec la France (Berkeley, CA, 1955), 161, 191-92, and 216-17.

${ }^{5}$ Crone and Skelton, 'English Collections', 83.
} 
alongside several other works (including the Two Treatises) which he had written anonymously. (The Publisher's Preface to the 1744 Collection drew attention to this fact) ${ }^{6}$

Perhaps the most interesting evidence of Locke's involvement in the Collection, however, is the striking similarity between his library and the Catalogue. Every one of the books of travels mentioned above appeared in both (except for that of Sandys, which had been printed in excerpt in Purchas, and would become one of two seventeenth-century publications added to the Catalogue in 1744-alongside Burnet's letters from the Continent, which Locke also owned) Both Locke's library and the Catalogue held as well, for example, the voyages of Pyrard, Hacke, Narborough, Dampier, Mocquet, Martin, Browne, Tavernier, Ovington, Terry, Hennepin, Olearius, Le Maire, and Maria, in addition to the histories of Bernier, de la Vega, Barros, Knox, Acosta, Gervaise, Gómara, de la Loubère, Ludolphus, Denys, and Mendoza. In 1699, Locke received from the Abbé Jean-Baptise du Bos, with whom he often corresponded regarding travel books, a note Locke marked in its margin as 'A list of Voyages lately published in France'. There were around thirty: Locke would come to own about twenty-two; and about twenty-five would appear in the Catalogue, including six of the seven books on Siam. The observation of Law in 1777, when he tentatively attributed both pieces of the Discourse to Locke, may thus be revised to say, 'That he was well versed in such authors [as those whose accounts were listed in the Catalogue] is pretty plain'. ${ }^{7}$

\footnotetext{
${ }^{6}$ For letters between Locke and Awnsham on the subject of the Churchill Collection, see for example CJL 2781; CJL 2864; CJL 2895; CJL 3097; CJL 3102; CJL 3112; CJL 3259; CJL 3295; CJL 3366; and CJL 3383. For letters between Locke and other correspondents, in the course of Locke's attempts to find books that likely were intended for the Collection, see for example CJL 2483; CJL 2571; CJL 2573; CJL 2632; CJL 2770; CJL 2799; and CJL 2837. The original edition of the Churchill Collection was dated 1704, but the work appeared on November 8, 1703. (See CJL, ed. de Beer, VIII, 122 [fn. 1].) For the 1704 Churchill Collection in Locke's library, see LJL 3118. For the codicil to Locke's will, see CJL, VIII, 426-27: quoted in 1744 Collection, vol. 1, Publisher's Preface (N.B.).

${ }^{7}$ CJL 2527; and [Law], 'Preface by the Editor', in Works of John Locke, I, iv. For the books of travels named in the first paragraph of this research note, see in $1704 \mathrm{Col}$ lection, vol. 1 (in order), lxxvii-lxxviii; lxxvii; lxxix-lxxx; xcii-xciii; xciii-xcv; lxxvii
} 
There are, moreover, several more general parallels between the travel books in Locke's library and those in the Catalogue. Both collections contained almost no ancient or medieval accounts. (The Catalogue did list one 1696 English edition of the fourteenth-century Travels of Sir John Mandeville, but noted that the book was "universally allowed to be fabulous," and Locke did not own a copy.) Both included none of the many popular travel books printed in Dutch, though both did have several Dutch accounts in translation, such as van Linschoten's record of voyages into the Indies and Exquemelin's history of the buccaneers of America. Both were concentrated above all in modern works in French and English. And both were well-balanced collections, which featured several descriptions of every region of the globe. ${ }^{8}$

In late remarks, which are usually known as 'Some Thoughts Concerning Reading and Study for a Gentleman', Locke listed books of travels that he thought one might want to know. He named Hakluyt, Purchas, Thévenot, and Ramusio, as well as several authors in both English and French. He noted that the Churchill Collection was printing just then, with travels 'never

(in de Bry); lxxvii (in de Bry) and xcv (in Purchas); (for Sandys, see below); xcviii; lxxxii; xcviii; lxxx; xcix-c; xcix; and xcvii. For Sandys, see Samuel Purchas, Hakluytus Posthumus or Purchas His Pilgrimes, 4 vols. (London, 1625-1626), bk. 6, ch. 8, 2: 896-920; and 1744 Collection, I, 'Continuation of the Catalogue and Character of most Books of Voyages and Travels down to the present Time, added to this new Edition', xxiii-xxix, xxiii. For Burnet, see xxiii-xxiv (as well as $L J L$ 527). For the works named in this paragraph, see in 1704 Collection, I, lxxxi (LJL 2411-2411a); xcvii (LJL 1370b); xcvii (LJL 2072); xcvii (LJL 910-11); xcv (in English) (LJL 2001-2002 [in French]); xcvi ( $L J L$ 1923); xcviii ( $L J L 498)$; 1xxx ( $L J L 2838)$; xcv ( $L J L 2160)$; xcvii ( $L J L 2857)$; xcvi (in English) (LJL 1421-1422 [in French]); xcviii (in English) (LJL 2128-2129 [in English and French]); 1xxxiv (LJL 1874); and 1xxix ( $L J L$ 1904)—as well as 1xxxv (LJL 285); 1xxxix ( $L J L$ 3088); lxxxviii (in Spanish) (LJL 210 [in Italian]); xcvii (LJL 1649); 1xxxix (in Spanish) (LJL 859 [in English]); lxxxiv (in French) (LJL 1245 [in English]); lxxxviii (in Spanish) ( $L J L 1254$ and 1254a [in French]); lxxxiii (LJL 1811-1811a); lxxvi ( $L J L$ 1830); lxxx-1xxxi ( $L J L$ 951); lxxxix (in Spanish) ( $L J L 1965-1965 b$ [in Italian, English, and Latin]).

${ }^{8} 1704$ Collection, I, xcvi. The Catalogue explained, with less than perfect accuracy, that it had not included works in Dutch, 'because they are not very many, and all of them will be found, as they were translated into other Languages'. For van Linschoten, see lxxvii (in de Bry) and LJL 507 (in de Bry); and for Exquemelin, see xcvi (in English) as well as 1xxxv (in French) and LJL 511-512 (in English). 
before in English, and such as are out of print'. 'There are besides these', he continued, 'a vast number of other Travels'. He said these were a 'sort of Books that have a very good mixture of delight and usefulness'. (In the Discourse, the Catalogue was offered to 'such as are addicted to this sort of pleasant and profitable Reading', in what was to be sure not an uncommon turn of phrase at the time.) 'To set them down all', Locke concluded, 'would take up too much time and room'. ${ }^{9}$ Perhaps he knew precisely how much time and room such a project would take up.

The evidence for Locke's authorship of the Catalogue is incomplete. The contents of his library do not match the contents of the Catalogue in several significant respects. ${ }^{10}$ Locke never directly acknowledged that he had composed, or even helped to compose, the Catalogue; and the work is not discussed specifically in his correspondence, including in letters with Awnsham. That said, it must also be noted that scholars who have maintained that Locke did not write the Catalogue have not closely considered the matter. The central source of modern opinion against Locke's authorship has been de Beer, who simply said, in a short research

${ }^{9}$ Locke, 'Extemporè Advice', 324; and 1704 Collection, I, lxxvi.

${ }^{10}$ Several works that Locke is known to have regarded as important-such as Sagard on Canada and on the Hurons, Bergeron on Tartary, and (in 1704) Sandys on the Middle East - are not mentioned in the Catalogue. (See, in order, LJL 2526-2527; LJL 280; LJL 2553; see also Locke, 'Extemporè Advice', 324.) In turn, of the more than two hundred separate titles listed in the Catalogue, perhaps dozens do not appear in Locke's library in any form. Several works that Locke owned as separate titles - such as de Léry on Brazil, Laudonnière on Florida, and Martyr on the Americas - appeared in the Catalogue only in the excerpted form in which they were printed in the collections of de Bry and Hakluyt, for example. (De Léry is listed above. For Laudonnière, see LJL 1681 [in de Bry, see 1704 Collection, I, xxvii; Hakluyt xciii]; and for Martyr, see LJL 1930, as well as $L J L$ 2101-2101a and $L J L 3156$ [in Ramusio lxxviii].) And several works that Locke only owned in excerpted form in larger collections - such as Alvarez on Ethiopia, Leo Africanus on northwestern Africa, and Oviedo on the West Indies-appeared in the Catalogue as separate titles. (For Alvarez, see lxxxviii [in Ramusio, LJL 2438; Purchas, LJL 2409]; for Leo, see lxxvi [in Ramusio, LJL 2438; Purchas, LJL 2409]; and for Oviedo, see lxxxix [in Ramusio, LJL 2438].) Finally, a number of books appeared in the Catalogue in languages different from the ones in which Locke owned them. This was most notably true of works in Spanish - which Locke read in French, English, Italian, or Latin translation but which for the most part were listed in the original in the Catalogue: see lxxxvi-xcii. 
note, that he 'had not checked the books mentioned in [the Catalogue] by the catalogue of Locke's library, but some of them he did not possess'. De Beer proposed that the Catalogue had been written instead by the clergyman Edward Wells (1667-1727), but also reported that he had 'not tested his writings for style'. If he had, he would have found that Wells was a scholar of geography rather than travels, whose several works in this field exhibited exactly the kind of detailed interest in the comparison of 'Antient and Present Geography', as he put it, and in particular in the geography of the Biblical world, which was nowhere evident in the books of travels in the Catalogue or in Locke's library. Moreover, Halley, the astronomer, was not nearly as knowledgeable in the genre as Locke (as is clear from the contents of Halley's library). And for his part Hans Sloane, the physician and naturalist whom Churchill also consulted in the preparation of the Collection, was, unlike most authors whose works appeared in the Catalogue, far more concerned with the natural than the human world-even though it is true that Sloane had in part gained the encyclopedic knowledge of the flora and fauna of the New World to which his books spectacularly attest from wide reading among travelers' accounts. ${ }^{11}$

The short 'Continuation' to the Catalogue included in the 1744 Collection referred to the 'editors' who had brought together the original version. There may well have been more than one: in-

${ }^{11}$ De Beer, 'Books Attributed to Locke', 50; and de Beer, 'Books Attributed to Locke', 51. See Edward Wells, A New Sett of Maps both of Antient and Present Geography (Oxford, 1700); Edward Wells, A Treatise of Antient and Present Geography (Oxford, 1701); Edward Wells, An Historical Geography of the New Testament, 2 vols. (London, 1708); and Edward Wells, An Historical Geography of the Old Testament (3 vols., London, 1711-1712). De Beer asserted that the Churchills had printed the second of these works, but in fact they had only printed its second edition: Edward Wells, $A$ Treatise of Antient and Present Geography (London, 1706; orig. pub. 1701). For Halley, see Scientists (vol. 11), ed. H. A. Feisenberger, in Sale Catalogues of Libraries of Eminent Persons, ed. A. N. L. Munby (London, 1975), 149-296. Talbot notes that Halley owned 160 books of travel in a library of almost 6,000 books (Locked owned around 4,000), but many of these were purchased after 1704. For Sloane, see Hans Sloane, Catalogus Plantarum qua in Insula Jamaica (London, 1696); and Hans Sloane, A Voyage to. . .Jamaica (London, 1707-1725): the latter appears in Locke's library as LJL 2864. 
deed, that several works in the Catalogue were described twice, in quite different terms, suggests that this was so. Grelot's voyage to Constantinople, for example, was in one place said to be a 'curious account', in a summary of one sentence, and yet elsewhere was praised, in a full paragraph, as 'among the best books of travels', which no lesser person than the King of France had read in draft form. Similarly, de Bry's collection, which was printed between 1590 and 1624, was praised for having included 'all the voyages and discoveries of any note till the time it was published' and was, on the same page in the Catalogue, set aside in favor of Ramusio, whose collection of 1550 to 1559 was judged to be 'much more complete and full than the Latin de Brye'. ${ }^{12}$ If Locke's precise role in what appears to have been the complex composition of the Catalogue must for now remain unknown, that he did play a role in the project seems beyond doubt. The burden of proof here falls, it is true, upon those who would give evidence of his role, and one hopes and suspects that there is more such evidence yet to come to light.

Harvard University

121744 Collection, I, xxiii; lxxvi; xciii; lxxiii; and lxxiii. (LJL does not contain Grelot's account.) For other works that were described twice in the Catalogue in different terms, see Choisy on Siam (lxxvii and lxxix), Gervaise on Siam (lxxvii and lxxix-lxxx), and Dellon on the West Indies (lxxvii and lxxx). 